\title{
STRATEGI PENGEMBANGAN INDUSTRI PENGOLAHAN KOMODITAS RUMPUT LAUT E. COTONII UNTUK PENINGKATAN NILAI TAMBAH DI SENTRA KAWASAN INDUSTRIALISASI \\ Strategy of Commudity Precessing Industry Depelopment \\ E. cottonii Seaweed to Increasing Value Added in The Area Center of Industrialization
}

\author{
*Hikmah \\ Balai Besar Penelitian Sosial Ekonomi Kelautan dan Perikanan \\ Gedung Balitbang KP I Lt. 4 \\ Jalan Pasir Putih Nomor 1 Ancol Timur, Jakarta Utara \\ Telp: (021) 64711583 Fax: 64700924 \\ *email: hikmah_madani@yahoo.com
}

Diterima 20 Maret 2015 - Disetujui 6 Juni 2015

\begin{abstract}
ABSTRAK
Tulisan ini bertujuan untuk mengkaji tentang potensi dan peluang, $p$ ermasalahan serta pengembagan industri rumput laut. Rumput laut merupakan salah satu komoditas perikanan budidaya yang mampu meningkatkan perekonomian masyarakat, menyerap tenaga kerja dan meningkatkan devisa negara. Potensi sebaran rumput laut di Indonesia sangat luas baik yang tumbuh secara alami maupun yang dibudidayakan di laut. Peluang menuju pengembagan Industri rumput laut masih terbuka di lihat dari potensi lahan budidaya, ketersediaan bahan baku, maupun dari sisi permintaan produk olahan. Permasalahan dan tantangan terkait kemampuan Indonesia dalam mengekspor dan bersaing dalam perebutan pangsa pasar dunia untuk pemenuhan kebutuhan rumput laut dunia antara lain rendahnya kualitas dan kontinuitas bahan baku, permodalan, lemahnya sumberdaya manusia dan kelembagaan, serta permasalahan pemasaran produk rumput laut. Strategi kebijakan pengembangan industri pengolahan rumput laut $\mathrm{E}$. cotonii untuk peningkatan nilai tambah adalah peningkatan produktivitas dan kualitas rumput laut, pengembangan industri pengolahan rumput laut setengah jadi (ATC,SRC dan RC) secara bertahap di sentra kawasan produksi rumput laut, dan pengembangan skala usaha pengolahan rumput laut siap konsumsi dari skala tradisoinal menjadi skala industri.
\end{abstract}

Kata Kunci: industri, nilai tambah, pengolahan, rumput laut

\begin{abstract}
This paper aims to assess the potential and opportunities, problems and developing a seaweed industry. Seaweed is one aquaculture commodity that is able to improve the economy, provide employment and increase foreign exchange. Potential distribution of seaweed in Indonesia is very wide both naturally grown and cultivated in the sea. Opportunities towards developing a seaweed industry is still open in view of the potential for the cultivation of land, availability of raw materials and processed products from the demand side. Problems and challenges related to Indonesia's ability to export and compete in the race for market share to meet the needs of the world's seaweed were low quality and continuity of raw materials, capital, human resources and institutional weaknesses, as well as marketing problems seaweed products. Strategy of commudities E. cotonii seaweed processing industry to development increase the added value is increased productivity and quality of seaweed, seaweed processing industry development of semi-finished (ATC, SRC and RC) gradually in the central area of seaweed production, and the development of business scale processing of seaweed ready for consumption on the scale tradisoinal be scale industries.
\end{abstract}

Keywords: Industry, added Value, processing, seaweed 


\section{PENDAHULUAN}

Permintaan rumput laut mulai mengalami peningkatan sejak awal tahun 1980 untuk berbagai kebutuhan di bidang industri makanan, tekstil, kertas, cat, kosmetika dan farmasi. Menurut McHugh dan Lanier (1983) penggunaan rumput laut akan semakin meningkat di masa mendatang. Hal ini dibuktikan dengan tingginya permintaan rumput laut untuk kebutuhan industri dalam dan luar negeri, oleh karena itu upaya penyediaan bahan baku yang berkualitas dan berkesinambungan menjadi sangat penting.

Peningkatan produksi rumput laut masih cukup optimis untuk bisa dicapai mengingat tingginya daya dukung teknis dan potensi kawasan pengembangan yang masih terbuka luas untuk dimanfaatkan. Hanya saja, sampai saat ini siklus aquabisnis rumput laut masih menyisakan masalah yang cukup kompleks antara lain jaminan kualitas produksi DES (Dried Eucheuma Seaweed) di tingkat pembudidaya yang secara umum masih belum memenuhi standar eksport, serta stabilitas harga yang masih fluktuatif dimana 2 (dua) aktor ini yang menjadi momok bagi keberlangsungan Industri rumput laut (Concon, 2012). Hasil penelitian Luhur et al. (2012) usaha rumput laut di Kabupaten Konawe Selatan memiliki keunggulan komparatif dan daya saing yang lebih besar dibandingkan Kabupaten Lombok Timur. Menurut Porter (1990), keunggulan daya saing suatu wilayah ditentukan oleh 4 faktor pokok dan faktor penunjang. Empat faktor pokok tersebut adalah kondisi faktor produksi, kondisi permintaan pasar, factor industri terkait dan industri pendukung, serta strategi perusahaan, struktur dan persaingan. Sedangkan factor penunjangnya adalah peluang dan peranan pemerintah.

Potensi rumput laut Indonesia yang sangat menjanjikan dan dapat menjadi komoditi yang bisa berperan dalam pergerakan kemajuan ekonomi nasional. Terbukti, Indonesia menjadi salah satu produsen terbesar rumput laut jenis Euchema Cotonii dan menguasai $50 \%$ pangsa pasar dunia untuk memenuhi permintaan pasar ekspor dari industri kosmetik dan farmasi. Namun demikian, produk yang diekspor $80 \%$ masih dalam bentuk bahan mentah (raw material) yaitu berupa rumput laut kering. Walaupun Indonesia telah memiliki upaya pemasaran dan budidaya rumput laut yang cukup berkembang namun belum diimbangi dengan pengembangan pengolahan yang memadai. Hal ini terlihat dari hasil produksi rumput laut nasional baru sekitar $20 \%$ yang dapat terserap dan diolah oleh industri dalam negeri.

Oleh karena itu, strategi peningkatan nilai tambah melalui pengembangan industri pengolahan rumput laut $E$. cotonii di sentra-sentra kawasan industrialisasi ini selaras dengan program industrialisasi rumput laut yang diimplementasikan oleh KKP. Peraturan Menteri Kelautan dan Perikanan Republik Indonesia Nomor PER.27/ MEN/2012 yang menyebutkan bahwa industrialisasi rumput laut dimaksudkan untuk meningkatkan volume dan nilai produksi. Dengan adanya kegiatan industrialisasi rumput laut ditargetkan akan dapat meningkatkan diversifikasi produk yang bernilai tambah tinggi dan meningkatkan jumlah serapan tenaga kerja dan pendapatan pelaku usaha.

Tujuan penulisan makalah ini adalah untuk mengkaji tentang potensi dan peluang, permasalahan serta pengembagan industri rumput laut dan merumuskan strategi kebijakan pengembagan industri pengolahan rumput laut E. cotonii untuk peningkatan nilai tambah di sentra kawasan industrialisasi.

\section{METODOLOGI}

Penelitian ini dilakukan melalui pendekatan desk study dan dilakukan pada tahun 2013.Metode desk study merupakan salah satu upaya untuk mempelajari informasi, data dan laporan yang mempunyai relevansi dengan tujuan penelitian. Metode ini digunakan untuk pengumpulan dan penelaahan data ataupun informasi awal dan lanjutan yang relevan dengan permasalahan yang dikaji untuk mendapatkan kejelasan dalam upaya penyusunan landasan teori yang sangat berguna untuk memperkaya kerangka konsepsional dan desain metodologi serta referensi pada saat penyusunan laporan akhir studi.

Metode analisis data yang digunakan adalah metode deskriptif kualitatif dan kuantitatif. Studi deskriptif dilakukan dalam rangka untuk memastikan dan juga menggambarkan karakteristik dari variabel-variabel penting suatu situasi. Tujuan dari penelitian deskriptif adalah untuk menggambarkan aspek-aspek yang relevan terhadap fenomena yang menarik dari suatu individu maupun organisasi (Sekaran, 2000). Selanjutnya, Hasan (2002) menyatakan bahwa untuk dapat menggunakan metode deskriptif, maka seorang peneliti harus memiliki sifat represif, harus selalu mencari bukan 
menguji, memiliki kekuatan integratif, dan kekuatan untuk memadukan berbagai macam informasi yang diterimanya menjadi satu kesatuan penafsiran.

\section{POTENSI DAN PELUANG PENGEMBANGAN INDUSTRI RUMPUT LAUT}

Bicara peluang terhadap pasar perdagangan rumput laut dunia, Indonesia berada pada posisi yangmempunyai peluang besar dalam memasok kebutuhan bahan baku rumput laut. Sebagai gambaran tahun 2010 peluang kebutuhan rumput laut Eucheuma cottonii dunia mencapai 274.100 ton, dimana Indonesia mempunyai peluang memberikan kontribusi ekspor sebesar 80.000 ton atau sekitar $29,19 \%$, sedangkan peluang kebutuhan dunia akan rumput laut jenis Gracilaria sp mencapai 116.000 ton, dimana Indonesia mempunyai peluang kontribusi sebesar 57.500 atau sekitar 49,57\% (Cocon, 2012).

Berdasarkan potensi area yang dimiliki Indonesia yang masih belum optimal untuk di kembangkan, peluang menuju industrialisasi rumput laut sangat terbuka terutama di wilayah bagian Timur. Menurut Rajagukguk (2009), ada beberapa hal yang menjadi bahan perti Indonesia yang potensi terbesar adalah di Papua. Disamping itu, peluang pasar ekspor yang terbuka luas, juga belum ada batasan atau kuota perdagangan bagi rumput laut; teknologi pembudidayaannya sederhana, sehingga mudah dikuasai; siklus pembudidayaannya relatif singkat, sehingga cepat memberikan keuntungan; kebutuhan modal relatif kecil; merupakan komoditas yang tidak tergantikan, karena tidak ada produk sintetisnya; usaha pembudidayaan rumput laut tergolong usaha yang padat karya, sehingga mampu menyerap tenaga kerja merupakan peluang pengembangan industrialisasi rumput laut.

Anggadiredja et al. (2006) dalam Rajagukguk (2009), memperkirakan kebutuhan dunia terhadap produk olahan rumput laut lima tahun ke depan akan meningkat. Permintaan rumput laut meningkat sejalan dengan peningkatan jumlah penduduk dan pertumbuhan industri berbasis rumput laut, serta kecenderungan masyarakat dunia untuk kembali kepada produk-produk hasil alam. Berdasarkan kecenderungan ekspor dan impor produk olahan rumput laut selama periode 1999-2004. diperkirakan pasar dunia produk olahan rumput laut meningkat sekitar 10 persen setiap tahun untuk karaginan semirefine (SRC), agar, dan alginat untuk industri (industrial grade). Adapun alginat untuk makanan (food grade) meningkat sebesar 7.5 persen dan karaginan refine sebesar lima persen.

Peningkatan permintaan rumput laut dunia juga dapat dilihat dari peningkatan volume impor yang dilakukan oleh negara-negara importir. Jepang merupakan negara importir terbesar rumput laut dunia, diikuti oleh China pada posisi ke-dua, dan United States of America (USA) pada posisi ke-tiga. Selama kurun waktu 1999 hingga 2006, ketiga negara tersebut mengimpor 55.66 persen dari seluruh impor dunia, sesuai dengan data yang diperoleh dari FAO (Food and Agriculture Organization). Oleh karena itu, dapat dikatakan bahwa ketiga negara tersebut memiliki posisi penting bagi setiap eksportir dunia (Gambar 1).

Tabel 1. Perkiraan Kebutuhan Dunia terhadap Produk Olahan Rumput Laut (Dalam Ton).

Table 1. Estimated World Requirements for Seaweed Products Processed (In Tons).

\begin{tabular}{lccccc}
\hline $\begin{array}{l}\text { Jenis Produk/ Types } \\
\text { of products }\end{array}$ & $\mathbf{2 0 0 6}$ & $\mathbf{2 0 0 7}$ & $\mathbf{2 0 0 8}$ & $\mathbf{2 0 0 9}$ & $\mathbf{2 0 1 0}$ \\
\hline $\begin{array}{l}\text { Karaginan (RC) / } \\
\text { Carrageenan }\end{array}$ & 26,160 & 27,470 & 28,850 & 30,285 & 31,800 \\
$\begin{array}{l}\text { Karaginan (SRC) / } \\
\text { Carrageenan }\end{array}$ & 33,350 & 36,690 & 40,355 & 44,390 & 48,830 \\
$\begin{array}{l}\text { Agar / Jelly } \\
\text { Alginat (Food grade)/ }\end{array}$ & 12,357 & 13,600 & 14,970 & 16,470 & 18,120 \\
$\begin{array}{l}\text { Alginate } \\
\begin{array}{l}\text { Alginat (Industrial } \\
\text { grade)/ Alginate }\end{array}\end{array}$ & 10,730 & 11,530 & 12,400 & 13,330 & 14,330 \\
\hline
\end{tabular}

Sumber : Anggadiredja et al. (2006) dalam Rajagukguk (2009)/

Source : Anggadiredja et al. (2006) in Rajagukguk (2009) 


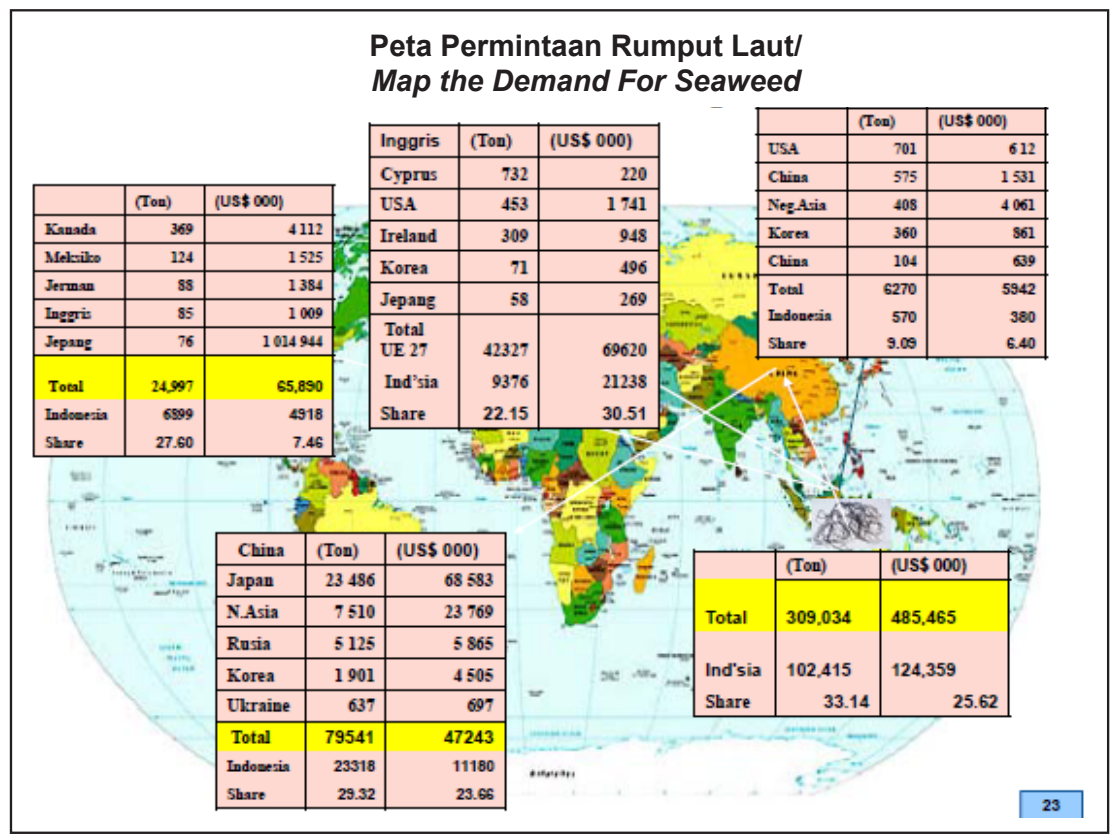

Sumber: Alex Retraubun, 2007/ Source: Alex Retraubun, 2007

\section{Gambar 1: Peta Permintaan Rumput Laut di Dunia}

Figure 1. Map the Demand For Seaweed

\section{PEMASALAHAN DAN TANTANGAN PENGEMBANGAN INDUSTRI RUMPUT LAUT}

\section{A. Kualitas dan Kotinyuitas Bahan Baku di Sektor} Hulu

Mengingat tingginya permintaan rumput laut untuk kebutuhan industri dalam dan luar negeri pengembagan industri rumput laut menjadi sangat penting. Sehubungan dengan hal tersebut, Direktorat Jenderal Perikanan Budidaya Kementerian Kelautan dan Perikanan berupaya mendukung kebutuhan tersebut melalui sebuah program peningkatan produksi perikanan budidaya dengan sasaran produksi perikanan sebesar 16.891.000 ton pada tahun 2014 atau meningkat sebesar 353\% bila dibandingkan tahun 2009. Dalam program tersebut rumput laut merupakan salah satu komoditas utama yang dikembangkan. Sasaran produksi rumput laut pada tahun 2014 adalah sebesar 10.000.000 ton (DJPB, 2009).

Untuk memenuhi target tersebut maka diharapkan terjadinya peningkatan produktivitas mengingat pada tahun 2012 produksi rumput laut baru mencapai 5,2 juta ton dari target produksi 10 juta ton pada tahun 2014. Namun, yang menjadi kendala adalah masih terdapat faktor-faktor penghambat peningkatan produktivitas dan kualitas rumput laut mulai dari produksi hingga penanganan pasca panen. Salah satu yang menjadi penentu dalam keberhasilan produksi budidaya rumput laut adalah pemilihan lokasi budidaya yang tepat. Saat ini yang menjadi permasalahan dari segi penetuan lokasi budidaya adalah belum adanya pengembangan peta kawasan pengembangan tata ruang yang ditunjang oleh daya dukung lingkungan, sehingga pengembangan budidaya rumput laut belum optimal dan berkelanjutan. Dalam kegiatan budidaya rumput laut permasalahan yang sering muncul adalah tidak tepatnya suatu lokasi kegiatan budidaya dengan metode budidaya yang digunakan sehingga penentuan lokasi budidaya menjadi sangat menentukan berhasil tidaknya suatu usaha budidaya rumput laut.

Dari segi input produksi berupa bibit, saat ini bibit yang dipakai dan dikembangkan oleh masyarakat masih didapat dari hasil pengembangan secara vegetatif yaitu dengan cara menyisihkan thallus hasil budidaya milik sendiri. Keterampilan untuk menyeleksi thallus yang baik untuk bibit sangat beragam dan sebagian besar dari masyarakat masih memiliki ilmu pengetahuan dan keterampilan yang sangat terbatas sehingga hasil produksi panen yang dihasilkan sering tidak optimal. Terbatasnya sentra pembibitan untuk menunjang kawasan-kawasan pengembangan budidaya rumput laut juga menyulitkan pembudidaya dalam mendapatkan bibit yang berkualitas. 
Rendahnya penguasaan teknologi mulai dari pembibitan, pembudidayaan, pemanenan dan pengeringan rumput laut juga menjadi masalah yang cukup krusial dalam meningkatkan produktivitas budidaya rumput laut. SDM yang ada saat ini masih memiliki tingkat pendidikan dan tingkat pengetahuan serta keterampilan terkait dengan pengembangan teknologi perikanan budidaya yang cukup rendah. Hal ini dikarenakan masih rendahnya penerimaan akses permodalan, informasi, teknologi dan pemasaran hasil perikanan yang berdampak pada rendahnya skala pengembangan usaha yang pada akhirnya rendahnya pada peluang kesempatan kerja yang tercipta.

Penanganan pasca panen memegang peranan sangat penting dalam industri rumput laut. Penanganan pasca panen menentukan mutu rumput laut yang dihasilkan sebagai bahan baku untuk pengolahan. Kegiatan ini harus dilakukan dengan seksama mulai dari cara panen, pencucian, pengeringan, pengemasan dan penyimpanannya. Rumput laut dipanen harus berumur 45 hari. Pencucian harus menghasilkan tingkat kebersihan yang memenuhi syarat seperti kadar garam dan kotorannya di bawah $5 \%$. Pengeringan harus dapat mencapai kadar air cukup rendah sehingga bahan baku tersebut layak jual ke pabrik atau eksportir. Rumput laut kering yang dijual petani pembudidaya mempunyai kadar air maksimum 35\% untuk Euchema (DJPB, 2009) dan sesuai dengan SNI 01-2690-1992 (Kementerian Pertanian, 1998).

Namun, permasalahannya adalah banyak dijumpai di Kabupaten Parigi Moutong usia panen yang masih muda dan penanganan pasca panen yang kurang baik. Petani seringkali memanen rumput lautnya kurang dari waktu panen yang dianjurkan yaitu 45 hari hal ini menyebabkan kandungan karaginan menjadi rendah. Petani juga tidak melakukan penjemuran rumput laut di tempat penjemuran yang baik, dimana masih banyak petani rumput laut yang menjemur rumput lautnya di atas pasir dengan hanya menggunakan jaring/terpal tanpa para-para. Hal ini menyebabkan banyaknya kotoran yang tersangkut pada rumput laut yang sedang dijemur. Selain itu petani juga tidak menerapkan penjemuran rumput laut hingga kadar air yang ditetapkan. Seringkali kadar air rumput laut yang dibeli dari petani bisa mencapai di atas $40 \%$ sehingga kadar garamnya pun bisa mencapai lebih dari $5 \%$. Hal ini akan menyebabkan rumput laut rusak pada saat penyimpanan dan proses distribusi. Untuk memperbaiki kualitas tersebut seringkali eksportir atau pabrikan harus mengeringkan kembali dan membersihkan garam yang menempel pada rumput laut, hal ini tentu memerlukan biaya tambahan dan mengakibatkan penyusutan berat akibat pengeringan ulang dan pembersihan garam.

B. Kualitas dan Kontinyuitas Bahan Baku di Sektor Hilir

Saat ini sekitar $80 \%$ rumput laut Indonesia hanya diekspor sebagai bahan baku primer (raw material) dalam bentuk rumput laut kering dengan harga relatif rendah, dan hanya $20 \%$ saja yang diolah di dalam negeri. Hal ini menyebabkan nilai tambah yang dihasilkan oleh produk rumput laut cenderung minim. Padahal rumput laut merupakan komoditas yang mampu menghasilkan nilai tambah yang cukup tinggi apabila telah melalui proses pengolahan. Sebagai gambaran, harga rumput laut kering di pasar internasional hanya 2 dollar AS per kilogram, padahal rumput laut olahan dapat dihargai 20 dollar AS per kilogram. Berikut merupakan tabel nilai tambah yang dihasilkan produk rumput laut.

Tabel 2. Nilai Tambah Produk Rumput Laut.

Table 2. Value-Added of Seaweed Products.

\begin{tabular}{|c|c|c|c|}
\hline $\begin{array}{l}\text { Produk/ } \\
\text { Products }\end{array}$ & $\begin{array}{l}\text { Rendemen }(\%) / \\
\text { Rendement }(\%)\end{array}$ & $\begin{array}{l}\text { Harga/ Prices } \\
\text { (Rp/kg) }\end{array}$ & $\begin{array}{c}\text { Nilai Tambah/ } \\
\text { Value Added (\%) }\end{array}$ \\
\hline $\begin{array}{l}\text { Rumput Laut Kering/ } \\
\text { Dried seaweed }\end{array}$ & $\begin{array}{l}12 \% \text { dari rumput laut basah/ } \\
\text { Wet seaweed }\end{array}$ & 7,000 & - \\
\hline $\begin{array}{l}\text { ATC Chips } \\
\text { (Industrial Grade) }\end{array}$ & $\begin{array}{l}31,5 \% \text { dari rumput laut kering/ } \\
\text { Dried seaweed }\end{array}$ & 60,000 & $270 \%$ \\
\hline SRC (Food Grade) & $\begin{array}{l}25 \% \text { dari rumput laut kering/ } \\
\text { Dried seaweed }\end{array}$ & 80,000 & $285 \%$ \\
\hline RC (Food Grade) & $\begin{array}{l}23,6 \% \text { dari rumput laut kering/ } \\
\text { Dried seaweed }\end{array}$ & 200,000 & $674 \%$ \\
\hline $\begin{array}{l}\text { Karaginan kertas/ } \\
\text { Carrageenan paper }\end{array}$ & $\begin{array}{l}25 \% \text { dari rumput laut kering/ } \\
\text { Dried seaweed }\end{array}$ & 95,000 & $339 \%$ \\
\hline
\end{tabular}

Sumber: Concon, 2013/Source: Concon, 2013 
Besarnya produksi rumput laut di wilayah Indonesia, tidak di barengi oleh kapasitas produksi rumput laut kering. Saat ini, kapasitas produksi rumput laut kering hanya 180 ribu ton dari kemampuan panen 5,2 juta ton rumput laut basah di tahun 2012 (Kompas, 2013a). Sedangkan pada catatan KKP, nilai ekspor rumput laut pada tahun 2012 US\$ 178 juta dengan volume 174.000 ton. Ekspor terbesar ke China yakni 67.250 ton atau $38,6 \%$ dari total volume ekspor (Kemenperin, 2013). Dari sini terlihat bahwa sebagian besar produksi rumput laut kering lebih ditujukan ke pasar ekspor dibanding untuk pemenuhan kebutuhan domestik.

Kurangnya pasokan untuk kebutuhan domestik menyebabkan Indonesia juga masih mengimpor produk rumput laut dari beberapa negara produsen lain. Berdasarkan data Comtrade, pada tahun 2011 Indonesia mengimpor rumput laut sebanyak 682 ton. Sementara itu, Indonesia mengekspor rumput laut kering mencapai 159 juta ton tahun 2011. Selain itu untuk memenuhi kebutuhan domestik Indonesia juga mengimpor produk rumput laut olahan berupa karagenan dari negara lain. Berdasarkan data P2HP, sepanjang 2012 Indonesia masih mengimpor 700 ton karagenan (hasil ekstraksi rumput laut) dari China dan Filipina. Hal ini terlihat dari keadaan di lapangan yang menunjukan bahwa beberapa pabrik pengolahan rumput dalam negeri masih kekurangan bahan baku, sehingga terpaksa harus mengimpor rumput laut. Dari hal ini terlihat bahwa hukum pasar berlaku, dimana masyarakat pembudidaya akan menjual barangnya jika penawaran dari pedagang lebih tinggi dibandingkan dengan harga yang ditawarkan oleh pabrik pengolahan rumput laut walaupun marginnya kecil. Disamping itu melalui pedagang perantara produsen dapat memperoleh bayaran secara tunai atau dengan perantaraan waktu yang tidak lama. Ini berbeda dengan pabrik yang baru bisa membayarkan dalam tempo yang lebih lama (DJPB, 2009).

Sejauh ini, di Indonesia sudah ada 27 pabrik pengolahan rumput laut, namun baru dua di antaranya yang bisa memenuhi permintaan pasar karagenan sesuai dengan spesifikasi pasar, misalnya tepungnya masih kurang putih dibandikan dari China dan Filipina. Permintaan industri lokal bertumbuh, sementara pasokan karagenan yang sesuai permintaan dari dalam negeri masih kurang. Akibatnya, impor masih menjadi pilihan. Permintaan tertinggi karagenan tersebut berasal dari industri pengolahaan daging, seperti untuk membungkus sosis. Selain itu, caraginan juga digunakan sebagai bahan baku industri makanan dan minuman seperti eskrim (Kompas, 2013 ${ }^{\mathrm{b}}$ ).

Fenomena lain adalah dimana hampir keseluruhan Industri rumput laut nasional terkonsentrasi pada kota-kota besar seperti Jakarta dan Surabaya, dilain pihak konsentrasi industri hulu tersebar di Indonesia bagian timur (mulai dari Sulawesi, NTT, NTB, dan Maluku). Kondisi inilah saat ini yang menuai permasalahan khususnya rantai pasok (suplly chain). Pola rantai distribusi pasar yang panjang sangat mempengaruhi posisi tawar produk yang dihasilkan pembudidaya, sehingga nilai tambah produk belum mampu dirasakan oleh produsen di hulu (Concon, 2013).

\section{Skala Usaha Pengolahan Rumput Laut Siap Konsumsi Skala Mikro}

Permasalahan yang terjadi di lapangan mengenai usaha ini adalah kurangnya tenaga kerja dan modal serta asset usaha dalam proses pengolahan rumput laut siap konsumsi. Pengolahan rumput laut siap konsumsi mengandalkan tenaga kerja ibu-ibu rumah tangga ataupun istri pembudidaya, serta lebih mengandalkan pesanan dalam pemasarannya. Selain tenaga kerja, modal dan asset usaha yang dimiliki cukup terbatas sehingga hal tersebut menyebabkan produksi produk olahan rumput laut cukup sedikit yaitu rata-rata $100 \mathrm{~kg}$ per bulannya. Selain itu permasalahan lain yang dihadapi dalam peningkatan daya saing produk diversifikasi adalah belum adanya sertifikasi seperti P-IRT, sehingga menghambat perkembangan pemasaran produk. Bagi pelaku usaha pengolahan pengurusan P-IRT cukup rumit karena terkendala oleh jarak yang jauh dari sentra produksi dan sumberdaya yang kurang sehingga pengurusannya sulit terealisasi. Tidak adanya P-IRT ini menghambat proses pemasaran karena tidak bisa dipasarkan/ dijual ke luar kota, sehingga hanya dipasarkan di pasar lokal saja. Hal tersebut di atas berdampak pada penerimaan atau keuntungan usahanya para pelaku usaha pengolahan rumput laut siap konsumsi. Padahal nilai tambah produk olahan rumput laut siap konsumsi seperti dodol, manisan, keripik, tortila dan lain sebagainya terbilang cukup besar dan dapat meningkatkan kesejahteraan rumah tangga pelaku usaha pengolahan apabila dilakukan dalam skala yang lebih besar. 


\section{PERSPEKTIF PENGEMBANGAN INDUSTRI PENGOLAHAN RUMPUT LAUT}

Industri pengolahan rumput laut ternyata memiliki manfaat yang sangat besar, tidak hanya pada sektor hulunya tetapi juga pada sektor hilirnya. Komoditas rumput laut memiliki keterkaitan ke belakang dan ke depan. Keterkaitan ini didasarkan pada pembagian penggunaan teknologi dalam pengolahannya. Keterkaitan ke belakang diartikan bahwa produk yang dihasilkan masih menggunakan teknologi yang sederhana, yaitu mengolah rumput laut kering menjadi bahan setengah jadi, serta mengolah rumput laut menjadi makanan/minuman (contoh: dodol). Kemudian dari bahan setengah jadi ini diteruskan pada industri yang dapat menghasilkan bahan baku penolong seperti karaginan, agar, alginat, dan sebagainya. Selanjutnya dari bahan baku penolong tersebut digunakan pada industri yang berteknologi tinggi dan tercatat lebih dari 500 end product barang konsumsi yang menggunakan rumput laut sebagai bahan penolong dalam berbagai skala dan tingkatan, seperti industry dairy product, farmasi, kosmetik, teknologi bahan, dll.

Klaster yang dikembangkan merupakan kumpulan dari unit-unit usaha yang secara kolektif dapat memperbaiki kinerja dari klaster. Kumpulan dari unit usaha yang mempunyai orientasi yang sama ini dapat mengurangi berbagai biaya transaksi dalam distribusi barang. Sebagai contoh kolektivitas ini sangat diperlukan jika pasar meminta pasokan rumput laut dalam jumlah besar, jumlah yang demikian tidak dapat dipenuhi oleh satu unit usaha kecuali dipenuhi oleh beberapa unit usaha didalam klaster tersebut. Dengan kolektif seperti ini, unitunit usaha tersebut dapat memperbaiki tingkat efisiensi dan membangun suatu kerjasama dengan memanfaatkan potensi dari setiap unit usaha dalam memenuhi permintaan pasar.

Hasil identifikasi dilokasi penelitian komponen-komponen pembentuk kluster industrialiasisi rumput laut dapat dikelompokkan sebagai berikut: 1). Kelompok unit usaha yang mendukung proses produksi. 2). Kelompok unit usaha proses produksi rumput laut 3). kelompok usaha pengolahan 4). Kelompok unit usaha jasa distribusi barang 5). Kelompok jasa pendukung. Unit usaha pembentuk klaster tersebut dalam menjalankan usahanya harus berfungsi sinergi satu dengan lainnya dengan menempatkan diri secara proporsional pada posisi masing-masing. Fungsi itu dibangun berdasarkan hubungan kedepan (fordward lingkages), dan hubungan kebelakang (backward lingkages) dari masing masing unit usaha. Hubungan kebelakang industri pengolahan chip tergantung pada pedagang besar rumput laut tanpa garam (rumput laut kering tawar), usaha budidaya rumput laut, usaha pembenihan rumput laut, dan usaha penyedia sarana produksi. Sementara keterkaitan kedepan dari industri chip rumput laut tergantung pada jasa transportasi darat, industri makanan dan minuman dalam negeri, industri non makanan, jasa transportasi ekspor serta pasar ekspor. Industri ini juga kedepan terkait juga pada peran dari jasa perbankan, penelitian dan pengembangan dan instansi pemerintah.

Selain itu hubungan kebelakang industri pengolahan chip dan powder tergantung pada pedagang besar rumput laut bergaram, usaha budidaya rumput laut, usaha pembenihan rumput laut, dan usaha penyedia sarana produksi. Sementara keterkaitan kedepan dari industri powder dan chip rumput laut tergantung pada jasa transportasi darat, industri makanan dan minuman dalam negeri, industri non makanan, jasa transportasi ekspor serta pasar ekspor. Industri ini juga kedepan terkait juga pada peran dari jasa perbankan, penelitian dan pengembangan dan instansi pemerintah.

Saat ini keterkaitan kedepan dan kebelakang dari industri itu belum tertata dengan baik, artinya hubungan kerja sama dari setiap unit usaha tersebut dibangun atas mekanisme pasar. Hubungan yang demikian akan dapat mempengaruhi kinerja unit usaha kecil dengan modal yang terbatas.

\section{STRATEGI PENGEMBANGAN INDUSTRI PENGOLAHAN RUMPUT LAUT E. COTONII UNTUK PENINGKATAN NILAI TAMBAH}

Keberlanjutan indstri rumput laut ditentukan oleh jaminan kualitas dan kontinuitas produksi (sistem produksi), pasar (jejaring), modal usaha, dan jaminan untuk berusaha (regulasi) (Anggadiredja, 2007). Sedangkan untuk strategi pengembangannya, menurut Keppel (2008), dapat ditempuh melalui pemetaan dan penataan kawasan budidaya, pengembangan sistem usaha dalam kawasan, penguatan kelembagaan dan pemberdayaan pembudidaya. Sementara Pandelaki (2012) menyatakan pengembangan industri budidaya rumput laut harus pula di ikuti dengan pengembangan industri pengolahananya, karena nilai tambah rumput laut sebagian besar terletak pada industri pengolahannya. 
1. Peningkatan produktivitas dan kualitas rumput laut

- Penyediaan bibit rumput laut yang mudah dijangkau dan tahan penyakit melalui pengadaan kebun bibit di sentra-sentra produksi

- Memberikan pemahaman kepada masyarakat akan pentingnya memperhatikan kualitas rumput laut yang diproduksi mulai dari pra produksi sampai dengan pasca panen (umur tanam, jarak tanam, kadar air RL, kalender tanam) melalui advokasi dan pengawasan secara intensif

- Penyediaan gudang penyimpanan rumput laut bagi pembudidaya/ kelompok pembudidaya atau pembentukan kelembagaan logistik rumput laut

- Subsidi input produksi seperti para-para penjemuran

- Mengoptimalkan peran pemerintah daerah dalam mengadvokasi kemitraan antara pembudidaya dengan pedagang

- Mengoptimalkan peran pemerintah daerah dalam menyusun regulasi yang strategis termasuk didalamnya penyusunan masterplan, penataan tata ruang wilayah (RTRW) yang ditunjang oleh daya dukung lingkungan

- Mengoptimalkan peran pemerintah daerah dalam penentuan zonasi budidaya rumput laut yang sesuai dengan ekositem dan metode budidaya

- Mengoptimalkan peran pemerintah daerah untuk kemudahan investasi bagi pihak investor

2. Pengembangan industri pengolahan rumput laut setengah jadi (ATC, SRC, dan RC) secara bertahap di sentra-sentra produksi rumput laut

- Pemerintah memperkuat kemitraan antara industri pengolahan dengan pembudidaya di sentra produksi untuk menjamin kontinuitas bahan baku dan meningkatkan efisiensi produksi

- Pemerintah membatasi kuota ekspor rumput laut mentah/kering (raw material) secara bertahap dengan mengalihkan sebagian pangsa pasar ekspor ke domestik (industri pengolahan ATC, SRC dan RC)
- Mengoptimalkan berbantuan pabrik pengolahan rumput laut dari Kementerian Perindustrian dan pengembangan industri pengolahan rumput laut yang baru di lokasi industrialiasasi melalui sinergitas program antara Kementerian Perindustrian dengan KKP

- Pemerintah menjalin kerja sama dengan investor asing untuk alih teknologi industri pengolahan rumput laut melalui Training of Trainers (TOT) agar mampu menjadi industri yang berstandar internasional

- Pemerintah membuat kemudahan regulasi dan perizinan untuk mendorong tumbuhnya industri pengolahan rumput laut di sentra produksi

- Pemerintah mendorong pihak swasta untuk berinvestasi dengan membuka unit pengolahan rumput laut ATC, SRC dan RC di sentra produksi rumput laut melalui promosi dan konsolidasi antara pemerintah, investor dan pelaku utama

- Pemerintah memfasilitasi jaringan pemasaran antara industri pengolahan dengan industri manufaktur (farmasi, kosmetik, food grade, dsb)

3. Pengembangan skala usaha pengolahan rumput laut siap konsumsi dari skala mikro menjadi skala industri

- Penguatan modal melalui skim penjaminan kredit dengan bekerjasama dengan pihak perbankan dan Kementerian Koperasi dan UKM

- Memfasilitasi pelaku usaha pengolahan dalam manajemen keuangan usaha melalui pelatihan manajemen keuangan

- Pendampingan terhadap pelaku usaha pengolahan dalam pembuatan kemasan dan branding produk yang menarik dalam rangka peningkatan pengetahuan untuk peningkatan daya saing

- Sosialisasi dan pendampingan dalam rangka pembuatan P-IRT, sertifikasi halal, HACCP dalam usaha pengolahan rumput laut

- Memfasilitasi pelaku usaha dalam pemasaran hasil produk olahan rumput laut melalui event-event pameran, temu bisnis, dan temu mitra, dan juga promosi produk olahan rumput laut serta pembentukan jaringan pemasaran 


\section{PENUTUP}

Indonesia memiliki peluang yang sangat luas untuk pengembangan indutri rumput laut. Hal ini dilihat dari potensi luas lahan, produksi dan produktivitas rumput laut, potensi permintaan yang semakin positif. Dukungan potensi Indonesia dapat menjadikan Indonesia sebagai produsen utama rumput laut dunia, juga dapat menjadikan rumput laut sebagai salah satu sumber devisa yang patut dikembangkan. Di sisi lain, berbagai permasalahan dan tantang yang dihadapi industri rumput laut terutama kualias dan kotinyuitas bahan baku di sector hulu dan kontinyuias bahan baku di sector hilir. Kemampuan Indonesia dalam mengekspor dan bersaing dalam perebutan pangsa pasar dunia untuk pemenuhan kebutuhan rumput laut dunia serta kurangnya nilai tambah berupa produk olahan siap konsumsi relative sedikit.

Pengembangan industri budidaya rumput laut harus pula di ikuti dengan pengembangan industri pengolahananya, karena nilai tambah rumput laut sebagian besar terletak pada industri pengolahannya. Strategi yang dapat lakukan untuk pengembangan industri pengolahan rumput laut melalui; 1) Peningkatan produktivitas dan kualitas rumput laut, 2) Pengembangan industri pengolahan rumput laut setengah jadi (ATC, SRC, dan RC) secara bertahap di sentra-sentra produksi rumput laut dan 3) Pengembangan skala usaha pengolahan rumput laut siap konsumsi dari skala mikro menjadi skala industri.

\section{DAFTAR PUSTAKA}

Anggadiredja, J. T. 2007. Prospek Pasar Rumput Laut Indonesia di Pasar Global. Lokakarya Implementasi Program Berkelanjutan Sulawesi Selatan Menuju Sentra Rumput Laut Dunia. Makalah. Makasar, 7 Mei 2007

Concon. 2013. Pendekatan Pembangunan Industri Rumput Laut Pada Sentral Produksi Budidaya. Diakses dari website: http:// www.djpb.kkp.go.id/berita. $p h p$ ? id=889. Diakses pada tanggal 16 Desember 2013.

2012. Status Rumput Laut Indonesia Peluang dan Tantangan. Direktorat Produksi. Direktorat Jenderal Produksi Budidaya. Departemen Kelautan dan Perikanan. Jakarta. 10 hal.

Direktot Jenderal Perikanan Budidaya. 2009. Profil Rumput Laut Indonesia. Direktorat Jenderal
Perikanan B udidaya Direktorat Produksi. Jakarta.

Hasan, M. I. 2002. Pokok-Pokok Materi Metodologi Penelitian Dan Aplikasinya, Ghalia. Indonesia, Bogor.

Kementerian Perindustrian. 2013. Meningkatkan Ekspor Rumput Laut Olahan ke Eropa. Diakses dari website: http://agro.kemenperin. go.id/1846-Meningkatkan-Ekspor-Rumput-Laut-Olahan-Ke-Eropa. Diakses pada tanggal 16 Desember 2013

Kementerian Pertanian. 1998. Keputusan Menteri Pertanian No. 481 Tahun 1998. Penerapan Standar Nasional Indonesia (SNI) Komoditas Hasil Pertanian.

Keppel, C. R. 2008. Prospek Pengembangan Sumberdaya Rumput Laut di Sulawesi Utara. Makalah dalam Temu Usaha Rumput Laut. Dinas Perikanan dan Kelautan Provinsi Sulawesi Utara. Manado.

Kompas. 2013a. Kualitas Rumput Laut Olahan Indonesia Kalah dari Filipina. Diakses dari website: http://bisniskeuangan. kompas.com/read/2013/10/04/1310050/ Kualitas. Rumput.Laut.Olahan.Indonesia. Kalah.dari.Filipina. Diakses pada tanggal 17 Desember 2013

Kompas. 2013b. Produksi Rumput Laut Produk Olahan Impor Banjiri Pasar. Diakses dari website:http://bisniskeuangan.kompas. com/read/2013/05/28/20485276/Produksi. Rumput.Laut.Produk.Olahan.Impor.Banjiri. Pasar. Diakses pada tanggal 16 Desember 2013.

Luhur, E. S., C. M. Witimo dan M. Firdaus. 2012. Analisa daya saing rumput laut di Indonesia (studi kasus: kabupaten konawe selatan, sulawesi tenggara). Jurnal Sosial Ekonomi Kelautan dan Perikanan Volume 7 (1) : 55-66.

McHugh, D. J. and B. V. Lanier. 1983. The World Seaweed Industry and Trade, South China Sea Fisheries Development and Coordinating Programme Food Agriculture Organization of the United Nation, Manila. ADB/FAO Market Studies Vol. 6. 30pp.

Pandelaki, L. 2012. Strategi Pengembangan Budidaya Rumput Laut di Pulau Nain Kabupaten Minahasa Utara. Jurnal Perikanan dan Kelauan Tropis. Vol. VIII-2. Unsrat. Sulawesi Utara. 
Peraturan Menteri Kelautan dan Perikanan Nomor PER.27/MEN/2012 tentang Pedoman Umum Industrialisasi Kelautan dan Perikanan. Ditetapkan di Jakarta pada tanggal 27 Desember 2012. Kementerian Kelautan dan Perikanan. Jakarta.

Porter, M. E. 1990. The Competitive Advantage of Nations. The Free Press. New York.

Rajagukguk, M. M. 2009. Analisis Daya Rumput Laut Indonesia di Pasar Internasional. [Skripsi, Tidak Diterbitkan]. Departemen Agribisnis. Fakultas Ekonomi dan Manajemen. Institut Pertanian Bogor. Bogor.
Retraubun, A. 2007. Prospek Pengembangan Rumput Laut dan Kemaritiman dan Langkahlangkahnya. Bahan Presentasi.

Sekaran. 2000. Research Methods For Business: A Skill Building Aproach 3rd ed. John Wiley and Sons: Inc. 